\title{
Amyloid-beta Leads to Impaired Cellular Respiration, Energy Production and Mitochondrial Electron Chain Complex Activities in Human Neuroblastoma Cells
}

\author{
V. Rhein - G. Baysang $\cdot$ S. Rao $\cdot$ F. Meier $\cdot$ \\ A. Bonert · F. Müller-Spahn · A. Eckert
}

Received: 14 November 2008/ Accepted: 18 March 2009/Published online: 7 April 2009

(C) Springer Science+Business Media, LLC 2009

\begin{abstract}
Evidence suggests that amyloid-beta (A $\beta$ ) protein is a key factor in the pathogenesis of Alzheimer's disease $(\mathrm{AD})$ and it has been recently proposed that mitochondria are involved in the biochemical pathway by which $\mathrm{A} \beta$ can lead to neuronal dysfunction. Here we investigated the specific effects of $\mathrm{A} \beta$ on mitochondrial function under physiological conditions. Mitochondrial respiratory functions and energy metabolism were analyzed in control and in human wild-type amyloid precursor protein (APP) stably transfected human neuroblastoma cells (SH-SY5Y). Mitochondrial respiratory capacity of mitochondrial electron transport chain (ETC) in vital cells was measured with a high-resolution respirometry system (Oxygraph-2k). In addition, we determined the individual activities of mitochondrial complexes I-IV that compose ETC and ATP cellular levels. While the activities of complexes I and II did not change between cell types, complex IV activity was significantly reduced in APP cells. In contrast, activity of complex III was significantly enhanced in APP cells, as compensatory response in order to balance the defect of complex IV. However, this compensatory mechanism could not prevent the strong impairment of total respiration in vital APP cells. As a result, the respiratory control ratio (state3/state4) together
\end{abstract}

\footnotetext{
V. Rhein · G. Baysang $\cdot$ S. Rao $\cdot$ F. Meier $\cdot$ F. Müller-Spahn $\cdot$ A. Eckert $(\square)$

Association Research Group Department of Biomedicine, Neurobiology Laboratory for Brain Aging and Mental Health, Psychiatric University Clinics, University of Basel, Wilhelm Klein-Strasse 27, 4025 Basel, Switzerland

e-mail: anne.eckert@upkbs.ch

A. Bonert

Department of Pharmacology, Biocenter, J.W. Goethe University of Frankfurt, Frankfurt, Germany
}

with ATP production decreased in the APP cells in comparison with the control cells. Chronic exposure to soluble $\mathrm{A} \beta$ protein may result in an impairment of energy homeostasis due to a decreased respiratory capacity of mitochondrial electron transport chain which, in turn, may accelerate neurons demise.

Keywords Mitochondria · Amyloid-beta . SH-SY5Y cells · Respiration · Electron chain · Energy · ATP · Oxygen consumption

\section{Introduction}

Alzheimer's disease (AD) is the most frequent form of dementia among elderly individuals and is characterized by neuropathological hallmarks of extracellular amyloid plaques and intracellular neurofibrillary tangles in the brain of $\mathrm{AD}$ patients. Extensive evidences suggest that amyloidbeta $(\mathrm{A} \beta)$ protein, which is derived from its precursor protein APP, plays a pivotal role in the pathogenesis of AD. In addition, mitochondrial dysfunction and energy metabolism deficiencies have been recognized as earliest events in AD (Chagnon et al. 1995) and have been correlated with impairments of cognitive abilities in this clinical scenario (Blass 2003). The most consistent defect of mitochondrial electron transport chain enzymes in $\mathrm{AD}$ is the deficiency in cytochrome $\mathrm{c}$ oxidase (complex IV) activity in post-mortem brain tissues, as well as in other tissues, such as platelets from $\mathrm{AD}$ patients and $\mathrm{AD}$ cybrid cells (Cardoso et al. 2004a, b). Although, the specific mechanisms leading to mitochondrial failure in $\mathrm{AD}$ still remain unknown, a substantial body of evidence indicates that $\mathrm{A} \beta$ promotes neuronal degeneration and death by enhancing neuron vulnerability to increase in levels of 
oxidative stress and impairments in cellular energy metabolism (Gibson and Huang 2002; Mattson and Liu 2002). Interestingly, enzyme activities in mitochondrial respiratory chain and citric acid cycle, which are reduced in $\mathrm{AD}$, can be inhibited by $\mathrm{A} \beta$ in vitro. Furthermore, several findings have demonstrated $\mathrm{A} \beta$-induced mitochondrial damage, e.g., $\mathrm{A} \beta$ inhibited cytochrome $c$ oxidase (COX) activity, in isolated brain mitochondria (Canevari et al. 1999; Parker et al. 1994). However, results on how mitochondrial respiratory chain complexes and complex IV are affected by $\mathrm{A} \beta$ are rather inconsistent (Casley et al. 2002b; Cassarino and Bennett 1999; Swerdlow and Kish 2002). It has been recently proposed that toxic species of $\mathrm{A} \beta$ that intervene in molecular and biochemical abnormalities in AD may be intracellular oligomeric forms, instead of extracellular, insoluble deposits. According to this hypothesis, mitochondria could intervene in the mechanism by which intracellular $\mathrm{A} \beta$ triggers synaptic failure and neurodegeneration (Eckert et al. 2008). This idea is supported by in vivo evidence of $\mathrm{A} \beta$ accumulation within mitochondria in brain tissues of AD patients (FernandezVizarra et al. 2004; Lustbader et al. 2004) and mitochondrial structural abnormalities (Hirai et al. 2001). Taken together, these data indicate that mitochondrial dysfunction can play a major role in AD pathophysiology (Eckert et al. 2003; Leuner et al. 2007; Rhein and Eckert 2007).

To unravel the direct impact of $\mathrm{A} \beta$ on mitochondrial respiratory functions, we established a new high resolution respiratory protocol to investigate the respiratory capacity of mitochondrial electron transport chain (ETC) under physiological conditions in control and in wild-type APP stably transfected human neuroblastoma cells (SH-SY5Y). By means of stably transfected APP SH-SY5Y cells, which represent a neuronal cell line of human origin widely used in studies testing the effect of $\mathrm{A} \beta$ in vitro, we circumvent the artificial experimental design of most of the other studies, where isolated mitochondria were treated with high concentrations of $\mathrm{A} \beta$ in the micromolar range $(5-50 \mu \mathrm{M})$. In addition, we determined the activities of mitochondrial complexes I-IV composing ETC, as well as the ATP levels.

\section{Materials and Methods}

\section{Cell Culture}

Stably expressing cell lines were obtained by transfecting the human neuroblastoma SH-SY5Y with cDNAs (pCEP4 vector) containing either vector alone (control cells) or the entire coding region of human APP (APP695) (Scheuermann et al. 2001). Stably transfected cell clones were selected with hygromycin (Scheuermann et al. 2001). Cells were grown at $37^{\circ} \mathrm{C}$ in DMEM medium supplemented with $10 \%$ calf serum, $2 \mathrm{mM}$ L-glutamine, and $0.3 \mu \mathrm{g} / \mathrm{ml}$ hygromycin.

\section{Detection of $\mathrm{A} \beta$ Levels}

For the detection of secreted $\mathrm{A} \beta_{1-40}$, we used a specific sandwich enzyme-linked immunosorbent assay employing monoclonal antibodies (Keil et al. 2004). The ELISA was performed in accordance with the Abeta-ELISA kit by Biosource. The assay principle is that of a standard sandwich ELISA, which utilizes a monoclonal mouse antihuman Abeta ${ }_{1-16}$ capture antibody, a cleavage-site-specific rabbit anti-human Abeta $_{1-40} C$-terminal detection antibody and anti-rabbit IgG peroxidase-conjugated secondary antibody.

\section{Western Blot}

Equal amounts (10-20 $\mu \mathrm{g})$ of protein were loaded on a 4$20 \%$ acryamide gel (Invitrogen, Germany) to perform SDS-PAGE at $200 \mathrm{~V}$ for $50 \mathrm{~min}$. The probes were transferred to a PVDF membrane (Amersham Biosciences, Germany). Equal protein loading was confirmed by Ponceau Red staining (Sigma, Germany). Membranes were saturated with $5 \%$ nonfat dry milk for $1 \mathrm{~h}$, washed three times with TBST, and incubated with the primary antibody (monoclonal anti-APP/A $\beta$ W02, Stratech, UK, or antiactin, Santa Cruz, Germany), overnight at $4^{\circ} \mathrm{C}$. After washing with TBST, PVDF membranes were treated with anti-IgG, horseradish-coupled secondary antibody (Calbiochem, Germany), for $1 \mathrm{~h}$ at room temperature. The bands were specifically detected by enhanced chemiluminescence reaction (ECL, Amersham, Germany).

\section{Immunohistochemical Staining}

Cells were plated at a density of $4 \times 10^{5}$ cells on collagen treated coverslips. After 2 days growth, coverslips were fixed in PBS with $4 \%$ PFA at $37^{\circ}$ for $30 \mathrm{~min}$, then permeabilized with $0.1 \%$ Triton for $15 \mathrm{~min}$ and blocked with PBS $10 \%$ goat serum for $1 \mathrm{~h}$ at $37^{\circ} \mathrm{C}$. The coverslips were incubated for $1 \mathrm{~h}$ at $37^{\circ} \mathrm{C}$ with the primary antibody (monoclonal mouse anti-APP MAB348, Chemicon International, Switzerland, which recognizes amino acids 66-81 of the $N$-terminal of APP). After washing with PBS, they were incubated for $30 \mathrm{~min}$ at $37^{\circ} \mathrm{C}$ with the biotinylated secondary antibody anti-mouse IgG (Sigma, Switzerland). Then, they were incubated with Vectastain $\mathrm{ABC}$ reagent (Vector Laboratories Inc., Burlingame) containing avidin and horseradish peroxidase reagents for immunoperoxidase staining. Finally, slides were incubated with AEC substrate solution (Sigma, Switzerland) containing 3-amino-9-ethyl 
carbazole for localizing peroxidase in the cells by producing a red reaction product. Staining was assessed using a Zeiss Axiolab microscope. Black-and-white photographs were taken.

\section{Phase Contrast Microscopy and Morphological Anlysis}

For the morphological analysis, cells were seeded at a density of $4 \times 10^{4}$ cells $/ \mathrm{ml}$ on coverslips previously coated with $0.05 \mathrm{mg} / \mathrm{ml}$ collagen. Phase contrast pictures were taken from living neuroblastoma cells using a Zeiss Axiolab microscope equipped with a digital camera Zeiss AxioCam MRc.

\section{Preparation of Isolated Mitochondria}

Cells were incubated for $15 \mathrm{~min}$ in an ice-cold lysis buffer $\left[75 \mathrm{mM} \quad \mathrm{NaCl}, 1 \mathrm{mM} \quad \mathrm{NaH}_{2} \mathrm{PO}_{4}, 8 \mathrm{mM} \quad \mathrm{Na}_{2} \mathrm{HPO}_{4}\right.$, $250 \mathrm{mM}$ sucrose, $1 \mathrm{mM}$ Pefabloc, $0.05 \%$ digitonine, complete protease inhibitor mixture tablets ${ }^{\circledR}$ (Roche Diagnostics)]. Then, the cells were homogenized with a glass homogenizer (10 strokes at $400 \mathrm{rpm}$ and 5 strokes at $700 \mathrm{rpm}$ ), and the resulting homogenate was centrifuged at $800 \times g$ for $10 \mathrm{~min}$ at $4^{\circ} \mathrm{C}$ to remove nuclei and tissue particles. The supernatant 1 (S1) was saved and the pellet was resuspended in the lysis buffer. The homogenization step as well as the low-speed centrifugation step was repeated. The supernatant 2 (S2) was saved and added to the supernatant 1 . The combined mitochondria-enriched supernatants $(\mathrm{S} 1+\mathrm{S} 2)$ were centrifuged at $20,000 \times g$ for $15 \mathrm{~min}$ at $4^{\circ} \mathrm{C}$ to obtain the mitochondrial fraction. The pellet was resuspended in PBS and stored at $4^{\circ} \mathrm{C}$ until use, followed by determination of protein content (Lowry et al. 1951).

\section{Complex I Activity}

A total of $300 \mu \mathrm{g}$ of isolated mitochondria was solubilized in $n$-dodecyl $\beta$-D-maltoside (20\%). NADH:hexaammineruthenium(III)-chloride (HAR) activity was measured at $30^{\circ} \mathrm{C}$ in a buffer containing $2 \mathrm{mM} \mathrm{Na}{ }^{+} / \mathrm{MOPS}, 50 \mathrm{mM}$ $\mathrm{NaCl}$, and $2 \mathrm{mM} \mathrm{KCN}, \mathrm{pH} 7.2$, using $2 \mathrm{mM}$ HAR and $200 \mu \mathrm{M}$ NADH as substrates to estimate the complex I content. To determine NADH-ubiquinone oxidoreductase activity, $100 \mu \mathrm{M} n$-decylubiquinone (DBQ) and $100 \mu \mathrm{M}$ $\mathrm{NADH}$ were used as substrates and $5 \mu \mathrm{M}$ rotenone as inhibitor, as described previously (David et al. 2005; Djafarzadeh et al. 2000; Hauptmann et al. 2008). Oxidation rates of NADH were recorded with a Shimadzu Multi Spec-1501 diode array spectrophotometer $\left(\varepsilon_{340-400} \mathrm{~nm}=\right.$ $6.1 \mathrm{mM}^{-1} \mathrm{~cm}^{-1}$ ). Complex I activity was normalized to the complex I content of the mitochondrial preparation and is given as $\mathrm{DBQ} / \mathrm{HAR}$ ratio.

\section{Complex II Activity}

The assay was performed by following the decrease in absorbance at $600 \mathrm{~nm}$, which results in the reduction of 2,6dichlorophenolindo-phenol (DCIP) in $1 \mathrm{ml}$ of medium containing $60 \mathrm{mM} \mathrm{KH} \mathrm{KO}_{2} \mathrm{PO}_{4}(\mathrm{pH} 7.4), 3 \mathrm{mM} \mathrm{KCN}, 20 \mu \mathrm{g} / \mathrm{ml}$ rotenone, $20 \mathrm{mM}$ succinate, and $20 \mu \mathrm{g}$ mitochondrial protein. The reaction was initiated by the addition of $1.3 \mathrm{mM}$ phenazine methasulfate (PMS) and $0.18 \mathrm{mM} \mathrm{DCIP}$ as described previously (Aleardi et al. 2005). The extinction coefficient used for DCIP was $21 \mathrm{mM}^{-1} \mathrm{~cm}^{-1}$.

\section{Complex III Activity}

The oxidation of $50 \mu \mathrm{M}$ decylubiquinol obtained by complex III was determined using cytochrome $c$ as an electron acceptor as described previously (Krahenbuhl et al. 1991). Briefly, decylubiquinol is prepared by dissolving decylubiquinone $(10 \mathrm{mM})$ in ethanol acidified to $\mathrm{pH} 2$. The quinone is reduced with excess solid sodium borohydride. Decylubiquinol is extracted into diethylether:cyclohexane $(2: 1, \mathrm{v} / \mathrm{v})$ and evaporated to dryness under nitrogen gas, dissolved in ethanol acidified to $\mathrm{pH} 2$. The assay was

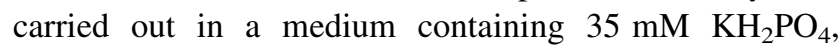
$5 \mathrm{mM} \mathrm{MgCl} 2,2 \mathrm{mM} \mathrm{KCN} \mathrm{(pH} \mathrm{7.2),} \mathrm{supplemented} \mathrm{with}$ $2.5 \mathrm{mg} / \mathrm{ml} \mathrm{BSA}, 15 \mu \mathrm{M}$ cytochrome $c, 0,6 \mathrm{mM} n$-dodecyl $\beta$-D-maltoside and $5 \mu \mathrm{g} / \mathrm{ml}$ rotenone. The reaction was started with $10 \mu \mathrm{g}$ of mitochondrial protein and the enzyme activity was measured at $550 \mathrm{~nm}$. The extinction coefficient used for cytochrome $c$ was $18.5 \mathrm{mM}^{-1} \mathrm{~cm}^{-1}$.

\section{Complex IV Activity}

Cytochrome $c$ oxidase activity was determined in intact isolated mitochondria $(100 \mu \mathrm{g})$ using Cytochrome $c$ oxidase assay kit. The colorimetric assay is based on the observation that a decrease in absorbance at $550 \mathrm{~nm}$ of ferrocytochrome $c$ is caused by its oxidation to ferricytochrome $c$ by cytochrome $c$ oxidase. The cytochrome $c$ oxidase Assay was performed as described previously (Rasmussen and Rasmussen 2000).

\section{Mitochondrial Respiration in Vital Cells}

Mitochondrial oxygen consumption was measured at $37^{\circ} \mathrm{C}$ using an Oroboros Oxygraph-2k system. Five millions of cells were added to $2 \mathrm{ml}$ of a mitochondrial respiration medium containing $0.5 \mathrm{mM}$ EGTA, $3 \mathrm{mM} \mathrm{MgCl}_{2}, 60 \mathrm{mM}$ K-lactobionate, $20 \mathrm{mM}$ Taurine, $10 \mathrm{mM} \mathrm{KH}_{2} \mathrm{PO}_{4}, 20 \mathrm{mM}$ HEPES, $110 \mathrm{mM}$ Sucrose, $1 \mathrm{~g} / \mathrm{l} \mathrm{BSA} \mathrm{(pH} \mathrm{7.1).} \mathrm{To} \mathrm{measure}$ the state 4 (=state 2 ) of the complex I, $5 \mathrm{mM}$ pyruvate and $2 \mathrm{mM}$ malate were added and the cells were permeabilised with $15 \mu \mathrm{g} / \mathrm{ml}$ digitonin. Afterward, $2 \mathrm{mM}$ ADP is added 
to measure state 3 respiration, and, in order to increase the respiratory capacity, $10 \mathrm{mM}$ glutamate was added. To study the effect of the convergent complex I + II electron input on the respiration, $10 \mathrm{mM}$ of succinate was added. The integrity of the mitochondrial membrane was checked by the addition of $10 \mu \mathrm{M}$ cytochrome $c$. After determining coupled respiration, $0.4 \mu \mathrm{M}$ FCCP (Carbonyl cyanide $p$ (trifluoro-methoxy) phenyl-hydrazone) was added and respiration was measured in the absence of a proton gradient. In order to inhibit complex I and III activities, $0.5 \mu \mathrm{M}$ rotenone and $2.5 \mu \mathrm{M}$ antimycine $\mathrm{A}$, respectively were added. Mock and APP cells were measured in parallel pairs using the same conditions (crossover design).

\section{Citrate Synthase Activity}

The reduction of 5,5'-dithiobis(2-nitrobenzoic acid) (DTNB) by citrate synthase at $412 \mathrm{~nm}$ (extinction coefficient of $13.6 \mathrm{mM}^{-1} \mathrm{~cm}^{-1}$ ) was followed in a coupled reaction with coenzyme $\mathrm{A}$ and oxaloacetate (Aleardi et al. 2005). Briefly, a reaction mixture of $0.2 \mathrm{M}$ Tris- $\mathrm{HCl}$, $\mathrm{pH} 8.0,0.1 \mathrm{mM}$ acetyl-coenzymeA, $0.1 \mathrm{mM}$ DTNB, $n$ dodecyl- $\beta$-D-maltoside (20\%) and $10 \mu \mathrm{g}$ of mitochondrial protein was incubated at $30^{\circ} \mathrm{C}$ for $5 \mathrm{~min}$. The reaction was initiated by adding $0.5 \mathrm{mM}$ oxaloacetate, and the absorbance change was monitored for $5 \mathrm{~min}$ with a Shimadzu Multi-Spec-1501 diode array spectrophotometer.

\section{Determination of ATP Levels}

Cells were plated 1 day before at a density of $2.5 \times 10^{4}$ cells/well in a white 96-well plate. The kit is based on the bioluminescent measurement of ATP. The bioluminescent method utilizes the enzyme luciferase, which catalyzes the formation of light from ATP and luciferin. The emitted light was linearly related to the ATP concentration and was measured using a luminometer (David et al. 2005; Keil et al. 2004).

\section{Statistical Analysis}

Data are presented as mean \pm S.E.M. For all statistical comparison, Student's $t$-test or Two-way ANOVA was used. $P$ values $<0.05$ were considered statistically significant.

\section{Results}

APP Expression and A $\beta$ Levels of APP Transfected SH-SY5Y Cells

In our cell model, the overexpression of human wild-type APP led to a significantly increased Aß secretion, as when compared with control cells with the empty vector. The APP expression of APPwt cells was substantially increased in comparison with the control cells (Fig. 1b, d) confirming previous findings (Scheuermann et al. 2001). The strong expression of APP was not correlated with a change of the general morphological aspect of APP cells when compared with the control cells (Fig. 1a). APP cells secreted A $\beta$ levels within $\mathrm{pg} / \mathrm{ml}$ range, reflecting the physiological situation in vivo during cellular metabolism (Fig. 1c). Using the APP SH-SY5Y cell line allows us to study effects of chronic stress of soluble forms of $\mathrm{A} \beta$ protein on cells and mitochondria, respectively, as it may occur in the brains of AD patients.

Amyloid-beta Leads to Mitochondrial Respiratory Defects

To investigate mitochondrial capacity and function of mitochondria in both control and APP cells, we initially focused on the activity of the citrate synthase (CS) in both cell types, which was similar in control and APP cells (Fig. 2a). Given the direct inhibitory effect of extracellular A $\beta$ on complex I (10\% inhibition) (Aleardi et al. 2005), we conducted direct measurements of the complex I activity. NADH-ubiquinone oxidoreductase (NADH:DBQ) activity in the mitochondrial APP cells did not alter, the same occurring for NADH:HAR activity, indicating that the complex I content was similar in both cell types. APP mitochondria did not exhibit any loss in complex I activity, as indicated by normalization of complex I activity with complex I content expressed as DBQ/HAR ratio (Fig. 2b). After normalization of complex I activity with the content of mitochondria, complex I/CS ratio did not modify between controls and APP cells (Fig. 2c). Moreover, activity of respiratory chain complexes II, III and IV were also normalized to the corresponding CS activity. Accordingly, we found an unchanged complex II (Fig. 2d), although there was a significantly up-regulated activity of complex III in APP cells compared with control cells (Fig. 2e). Similarly we observed a significantly reduced cytochrome $c$ oxidase activity between control and APP mitochondria (Fig. 2f), which is consistent with the reduced complex IV activity in platelets from AD patients (Cardoso et al. 2004a), and the direct interaction of $\mathrm{A} \beta$ with mitochondrial membranes, which results in the inhibition of complex IV in vivo (Canevari et al. 1999; Hauptmann et al. 2008).

In order to evaluate the functionality of the respiratory chain, we determined the physiological cell respiration in vital control and APP cells (Fig. 3). We used the NADH generating substrates, pyruvate and malate, to determine state 4 of respiration (Fig. 3). State 3 respiration measures the capacity of the mitochondria to metabolize oxygen and 
(a)

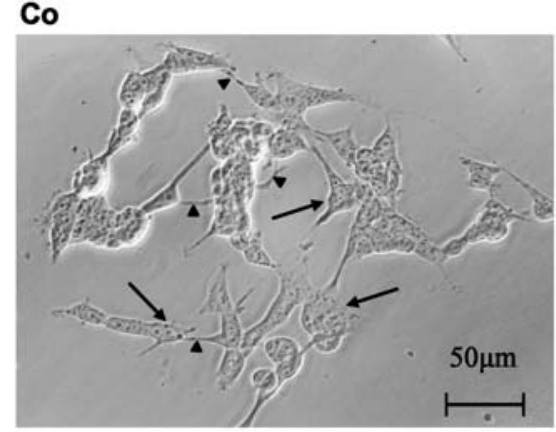

(b)

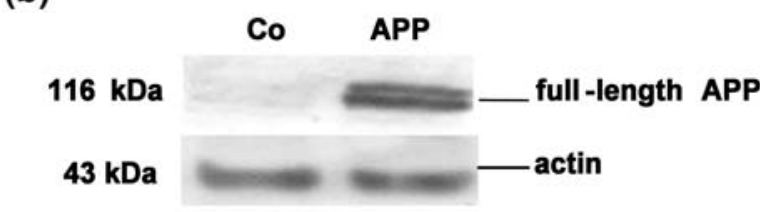

(c)

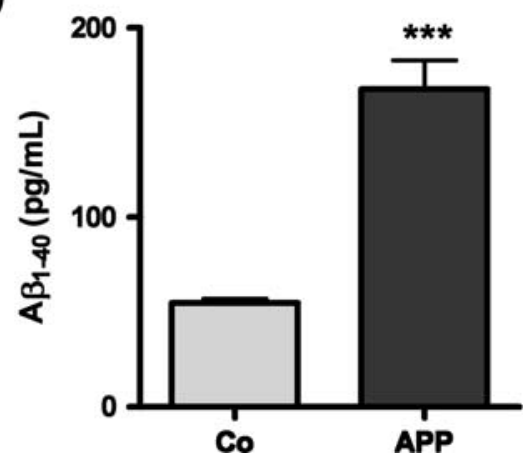

Fig. 1 Human APP and secreted $\mathrm{A} \beta_{1-40}$ levels of SY5Y cells. a Morphological analysis of native and transfected SH-SY5Y cells showed neuroblast-like morphology with differentiated perikaria (arrows) and occasional short neurites (arrowheads). Transfection of SH-SY5Y cells with cDNAs (pCEP4 vector) containg the vector alone or containing the entire coding region of human APP (APP695) did not significantly change the general morphological aspect of the cells. Scale bars $50 \mu \mathrm{m}$. b Human APP expression levels of SHSY5Y cells detected by western blotting using W02 antibody

the selected substrate in the presence of a defined amount of ADP, which is a substrate for the ATP synthase (complex V). State 4 respiration represents a "basal-coupled" rate of respiratory chain activity and reflects activities of respiratory chain complexes and proton leakage across the inner mitochondrial membrane. We observed a significantly reduced state 3 and state 4 respirations in the APP cells (Fig. 3c). The addition of another substrate of complex I, glutamate was not able to further increase cellular respiration driven by complex I in both cell types. Afterward, succinate was added as a substrate for complex II. In control cells, addition of succinate substantially increases total cell respiration, while in APP cells only a minor increase was observed (Fig. 3a). In addition, after uncoupling with FCCP, the respiratory rate increased in the

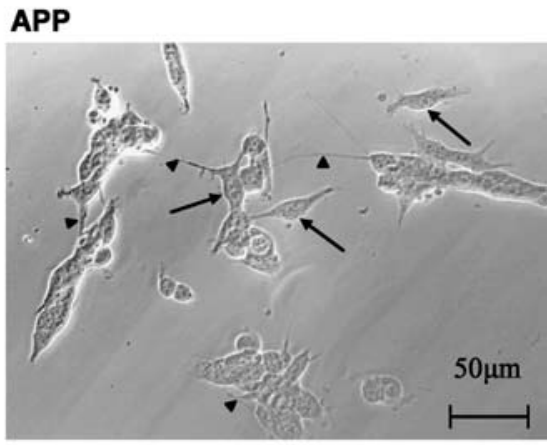

(d)

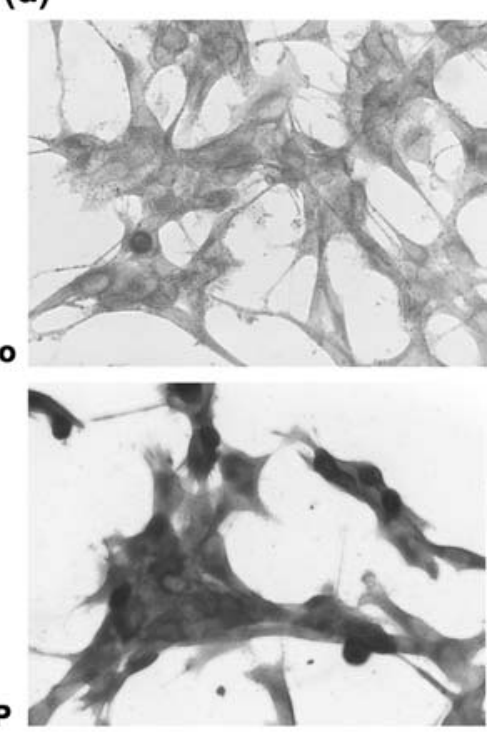

indicating strong expression of APP in APP transfected cells compared with control cells. c Cell culture supernatants of $5 \times 10^{6}$ SH-SY5Y cells (APPwt, Co) were collected and assayed for $\mathrm{A} \beta_{1-40}$ by ELISA. A $\beta_{1-40}$ levels were significantly enhanced in APP cells when compared with control cells ( $* * * P<0.001, n=6$, Student's $t$ test). d Human APP detected by immunochemistry using a monoclonal anti-APP antibody indicating stronger presence of APP in the APP cells compared to the endogenous APP expression in control cells

absence of a proton gradient, which indicates the maximum capacity of electron transport chain. This maximum capacity was significantly enhanced in the control cells in relation with the APP cells (Fig. 3a).

The respiratory control ratio (RCR) revealed a significant effect of $\mathrm{A} \beta$ on the coupling of mitochondrial respiration, indicating that the relative efficiency of metabolic coupling of electron chain complexes is impaired under conditions of chronic stress evoked by soluble forms of $\mathrm{A} \beta$ in our APP cell model (Fig. 4a). ATP levels were significantly reduced in APP cells (Fig. 4b). Taken together, these results suggest that soluble species of $\mathrm{A} \beta$ exhibit an initial defect in mitochondrial function with reduced complex IV activity that is translated into a mitochondrial respiration deficiency with diminished ATP synthesis, 
Fig. 2 Mitochondrial enzymes activities in control and APP cells. a Unaltered citrate synthase activity between control and APP cells. b complex I activity (DBQ activity) normalized to the complex I content (HAR activity) of the mitochondrial preparation is shown as DBQ/ HAR ratio. Complex I activity is unaltered. $\mathbf{c}$ unaltered complex I/CS ratio. d unaltered complex II/CS ratio. e complex III/CS ratio was significantly increased in the APP cells (***, $P<0.001$ vs. control cells, Student's $t$-test). $\mathbf{f}$ Complex IV/CS ratio was significantly decreased in the APP cells (**, $P<0.01$ vs. control cells, Student's $t$-test). All values represent the means \pm S.E. from $n=4-6$ independent experiments
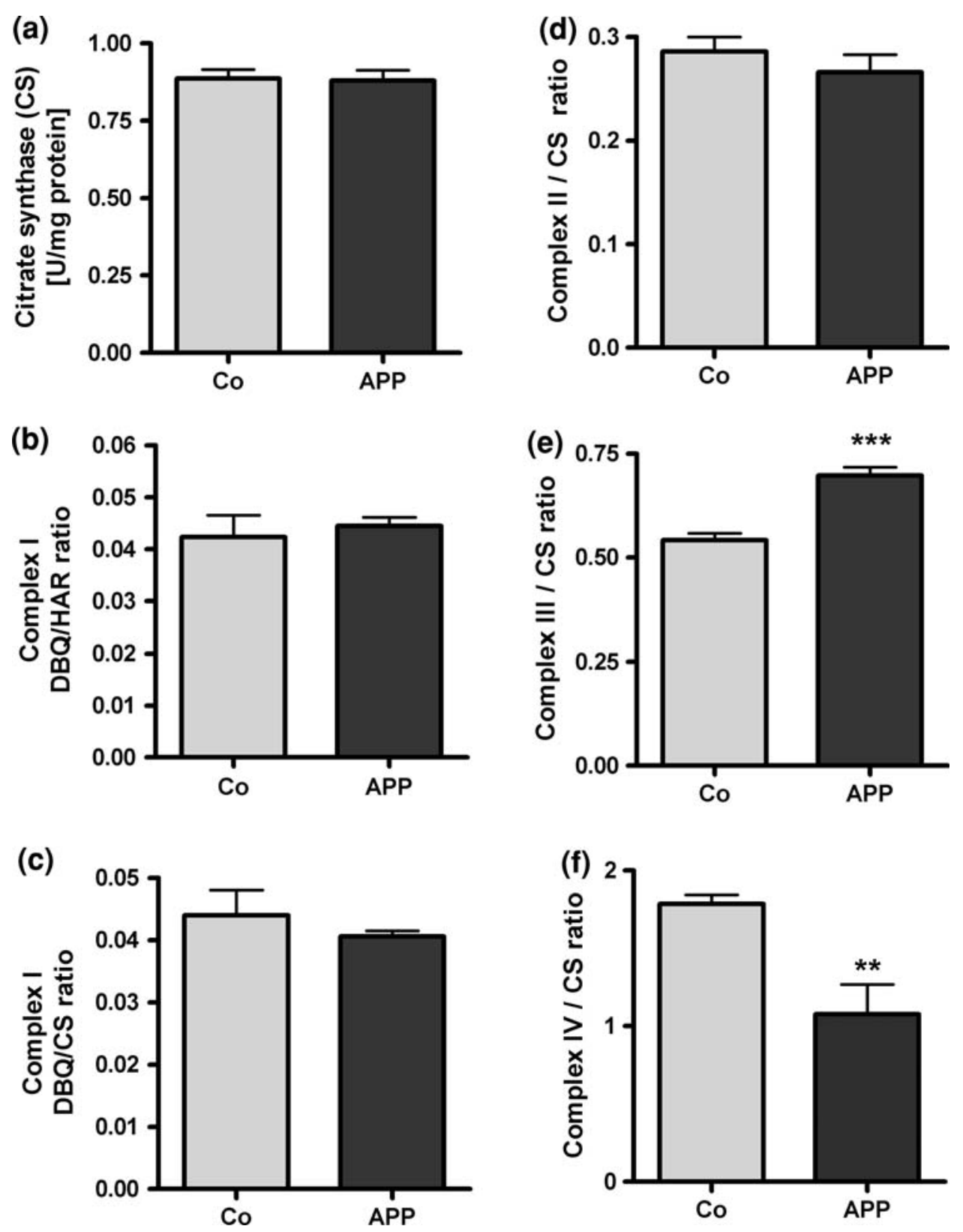

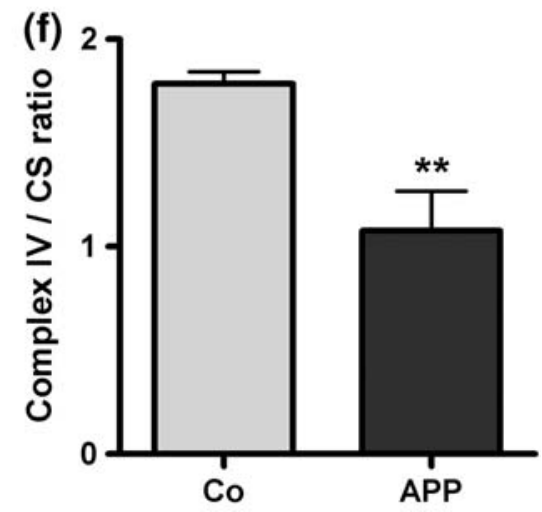

which cannot be compensated by an increased activity of complex III.

\section{Discussion}

A priori our findings support a toxic role of $\mathrm{A} \beta$ in respiration. Although the specific pathways that lead to energy deprivation in $\mathrm{AD}$ remain unclear, there is evidence in favor of $\mathrm{A} \beta$-induction of cell loss and synaptic failure by energy deprivation and oxidative stress (Gibson and Huang 2002; Mattson and Liu 2002). Recently, the focus on toxic species of $\mathrm{A} \beta$ has switched from its extracellular and fibrillar forms to its soluble species, e.g., oligomers, that can be detected intracellularly and may represent the primary toxic A $\beta$ correlate (Fernandez-Vizarra et al. 2004; Lustbader et al. 2004). Accoding to this novel hypothesis, mitochondrial dysfunction may play a crucial role in the biochemical pathway, by which $\mathrm{A} \beta$ can lead to neuronal dysfunction in AD (Eckert et al. 2008).

To unravel the effects of soluble species of $\mathrm{A} \beta$ on the mitochondrial respiratory capacity under physiological conditions, we established for the first time, a high resolution respiratory protocol to perform whole cell recording of total cellular respiration in control and with wild-type APP stably transfected human neuroblastoma cells (SH-SY5Y). We observed an impairment of oxygen consumption rate and a decrease of respiratory control ratio (state $3 /$ state 4 ) in 
(a) Control cells

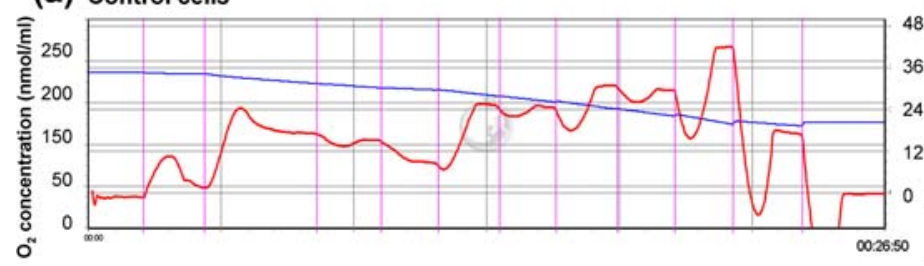

(b) APP cells

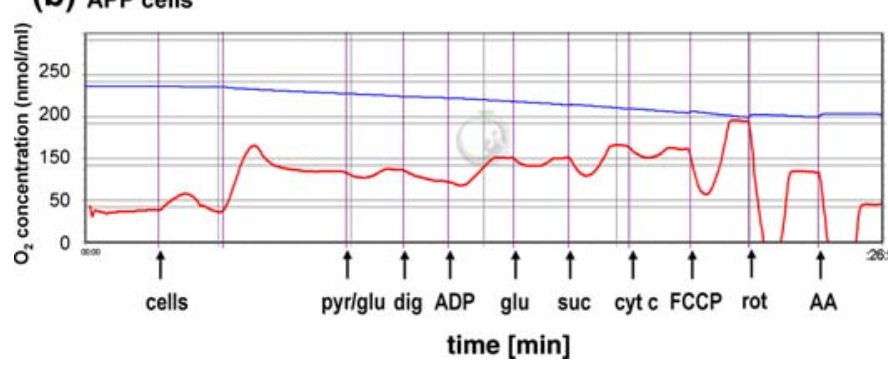

Fig. 3 High-resolution respirometry revealed a reduction of oxygen consumption in APP cells. Representative diagrams of measurement of oxygen $\left(\mathrm{O}_{2}\right)$ consumption in control cells $\mathbf{a}$ and in APP cells b demonstrating a decrease in the total $\mathrm{O}_{2}$ concentration with time. $\mathrm{O}_{2}$ flux and consumption by vital cells was measured after addition of different agents: pyruvate/glutamate ( $p y r / g l u)$, digitonin (dig), ADP, glutamate $(g l u)$, succinate $(s u c)$, cytochrome c $($ cyt $c)$, FCCP,
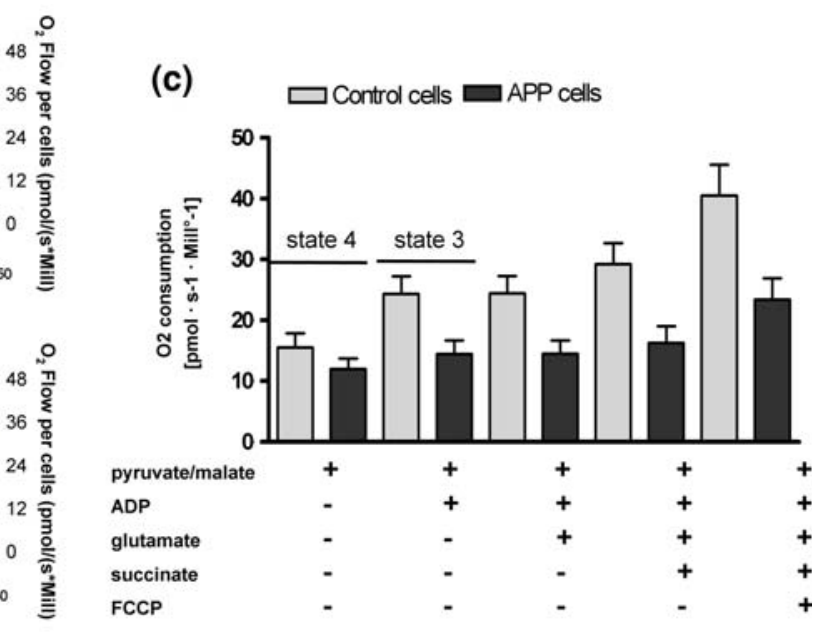

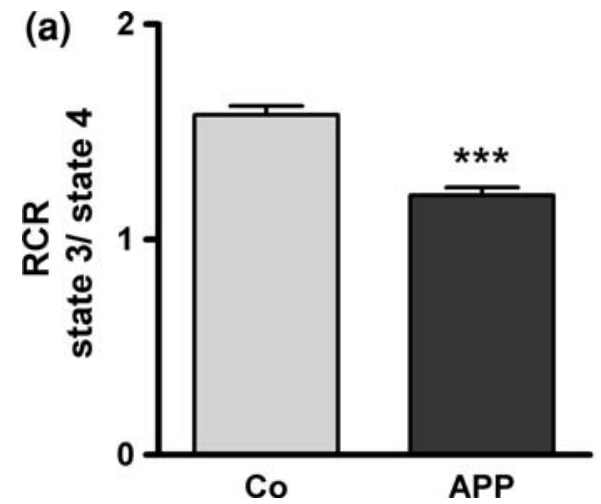

Fig. 4 Reduced respiratory control ratio (state3/state4) (RCR) and impaired ATP synthesis in APP cells. a Significantly reduced RCR in APP cells (***, $P<0.001$ vs. control cells, Student's $t$-test), indicating an impaired efficiency of electron transport. Values

the APP that might be induced by the chronic over expression of $\mathrm{A} \beta$ within the low nanomolar range. This defect of the whole mitochondrial respiratory chain may be explained by the accumulated dysfunctions of one or several mitochondrial chain complexes. To test this hypothesis, we measured individual activities of mitochondrial complexes I-IV as well as the ATP levels. Our results clearly show a decrease in complex IV activity in the APP cells, which is in accordance with the previous findings (Cardoso et al. 2004a; Caspersen et al. 2005; Hauptmann et al. 2008). Interestingly, the activity of the complex III significantly rotenone (rot), antimycine $\mathrm{A}(A A)$. $\mathbf{c} \mathrm{O}_{2}$ consumption in control and APP cells. Two-way ANOVA revealed a significant difference between the cellular respiration of the two cell types $(P<0.001)$. The respiratory rates of mitochondria were significantly reduced in APP cells. Values represent the means \pm S.E. from $n=5$ assays (cell type)

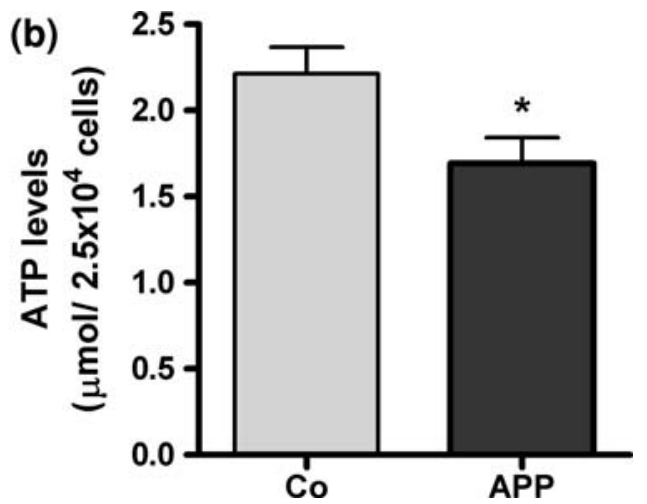

represent means \pm S.E. from $n=5$. b In accordance, ATP levels are significantly reduced in APP cells $\left(^{*}, P<0.05\right.$ versus control cells, Student's $t$-test).Values represent means \pm S.E. from $n=5$ (measurements of control and APP cells were performed in parallel)

increased, most probably as a compensatory mechanism in response to the toxic effect of $\mathrm{A} \beta$ on complex IV. Nevertheless, this compensatory response could not entirely balance or avoid the impairment of cellular respiration. This finding is in contrast to Caspersen et al. (2005). Accordingly, a decrease of complex III activity was revealed, together with a decrease of complex IV activity in brain tissues from APP transgenic mice at the age of 12 months. It is likely that in our cell model, we were able to detect a premature intervention mechanism in response to soluble forms of $\mathrm{A} \beta$ as a compensatory increase of complex III 
activity, whereas the strong $\mathrm{A} \beta$ load might have led to a breakdown of that response thus decreasing complex III activity. Moreover, we could show that complexes I and II were not affected by $\mathrm{A} \beta$, which is in accordance with findings on APP transgenic mice (Caspersen et al. 2005; Hauptmann et al. 2008). However, it contrasts to in vitro findings on isolated mitochondria, which were acutely treated with rather high concentrations of aggregated and fibrillar forms of $\mathrm{A} \beta(5-50 \mu \mathrm{M})$, which in turn can induce defects in nearly all complexes (Aleardi et al. 2005; Casley et al. 2002a, b). Thus, nearly all other studies used synthetic $\mathrm{A} \beta$ peptides in the micromolar range, many orders of magnitude over physiological levels, and cells or even isolated mitochondria were exposed only to synthetic $\mathrm{A} \beta$ fragments. By contrast, our neuroblastoma cell model represents a very valuable approach to investigate $\mathrm{AD}$-specific cell death pathways by studying $\mathrm{A} \beta$ levels within the picomolar range. This cell model attempts to mimic physiological conditions studying chronic effects of rather low concentrations of $\mathrm{A} \beta$ that are relevant for $\mathrm{AD}$ patients. The fact that the mitochondrial dysfunction in our APP cell model, especially the decrease in complex IV activity, is already observed at picomolar concentrations and higher amounts of synthetic $\mathrm{A} \beta$ are needed to achieve a comparable mitochondrial impairment also highlights the potential role of other APP fragments, e.g., the carboxy-terminal APP fragments (CTFs), which may accelerate the $\mathrm{A} \beta$-induced mitochondrial failure (Jin et al. 2002; Chang and Suh 2005). This is of special interest, since both, $\mathrm{A} \beta$ and CTFs, can accumulate intraneuronally. The neuronal loss and synaptic transmission deficit in $\mathrm{AD}$ may therefore depend on intraneuronal accumulation of A $\beta$ and CTFs (Jin et al. 2002; Chang and Suh 2005). Similarly, we showed that energy production was impaired in the APP cells, which is corroborated with other findings (Hauptmann et al. 2008; Keil et al. 2004).

One can speculate that in humans, increased accumulation and associated mitochondrial toxicity can be underlying factors in the pathogenesis of AD. Initially, the damaging effects of low physiological concentrations of $\mathrm{A} \beta$ may be partly compensated by an adaptive response, e.g., increased complex III activity. However, when agerelated secondary stress occurs, pronounced mitochondrial impairment might lead to the induction of cell death processes, while in familial $\mathrm{AD}$, high $\mathrm{A} \beta$ load might be directly responsible for mitochondrial and cellular dysfunction. In summary, we show novel and distinct actions of $\mathrm{A} \beta$ on mitochondria that may contribute to the pathogenic outcome.

Acknowledgments This research was supported by grant from the SNSF (Swiss National Science Foundation) \#310000-108223 to A.E.

\section{References}

Aleardi AM, Benard G, Augereau O, Malgat M, Talbot JC, Mazat JP, Letellier T, Dachary-Prigent J, Solaini GC, Rossignol R (2005) Gradual alteration of mitochondrial structure and function by beta-amyloids: importance of membrane viscosity changes, energy deprivation, reactive oxygen species production, and cytochrome c release. J Bioenerg Biomembr 37:207-225. doi: 10.1007/s10863-005-6631-3

Blass JP (2003) Cerebrometabolic abnormalities in Alzheimer's disease. Neurol Res 25:556-566. doi:10.1179/0161641031012 01995

Canevari L, Clark JB, Bates TE (1999) Beta-amyloid fragment 25-35 selectively decreases complex IV activity in isolated mitochondria. FEBS Lett 457:131-134. doi:10.1016/S0014-5793(99)01 028-5

Cardoso SM, Proenca MT, Santos S, Santana I, Oliveira CR (2004a) Cytochrome c oxidase is decreased in Alzheimer's disease platelets. Neurobiol Aging 25:105-110. doi:10.1016/S01974580(03)00033-2

Cardoso SM, Santana I, Swerdlow RH, Oliveira CR (2004b) Mitochondria dysfunction of Alzheimer's disease cybrids enhances Abeta toxicity. J Neurochem 89:1417-1426. doi: 10.1111/j.1471-4159.2004.02438.x

Casley CS, Canevari L, Land JM, Clark JB, Sharpe MA (2002a) Betaamyloid inhibits integrated mitochondrial respiration and key enzyme activities. J Neurochem 80:91-100. doi:10.1046/j.00223042.2001.00681.x

Casley CS, Land JM, Sharpe MA, Clark JB, Duchen MR, Canevari L (2002b) Beta-amyloid fragment 25-35 causes mitochondrial dysfunction in primary cortical neurons. Neurobiol Dis 10:258267. doi:10.1006/nbdi.2002.0516

Caspersen C, Wang N, Yao J, Sosunov A, Chen X, Lustbader JW, Xu HW, Stern D, McKhann G, Yan SD (2005) Mitochondrial Abeta: a potential focal point for neuronal metabolic dysfunction in Alzheimer's disease. FASEB J 19:2040-2041

Cassarino DS, Bennett JP Jr (1999) An evaluation of the role of mitochondria in neurodegenerative diseases: mitochondrial mutations and oxidative pathology, protective nuclear responses, and cell death in neurodegeneration. Brain Res Brain Res Rev 29:1-25. doi:10.1016/S0165-0173(98)00046-0

Chagnon P, Betard C, Robitaille Y, Cholette A, Gauvreau D (1995) Distribution of brain cytochrome oxidase activity in various neurodegenerative diseases. Neuroreport 6:711-715. doi: 10.1097/00001756-199503270-00002

Chang KA, Suh YH (2005) Pathophysiological roles of amyloidogenic carboxy-terminal fragments of the beta-amyloid precursor protein in Alzheimer's disease. J Pharmacol Sci 97:461-471. doi:10.1254/jphs.CR0050014

David DC, Hauptmann S, Scherping I, Schuessel K, Keil U, Rizzu P, Ravid R, Drose S, Brandt U, Muller WE, Eckert A, Gotz J (2005) Proteomic and functional analyses reveal a mitochondrial dysfunction in P301L tau transgenic mice. J Biol Chem 280:23802-23814. doi:10.1074/jbc.M500356200

Djafarzadeh R, Kerscher S, Zwicker K, Radermacher M, Lindahl M, Schagger H, Brandt U (2000) Biophysical and structural characterization of proton-translocating NADH-dehydrogenase (complex I) from the strictly aerobic yeast Yarrowia lipolytica. Biochim Biophys Acta 1459:230-238. doi:10.1016/S0005-2728 (00)00154-7

Eckert A, Keil U, Marques CA, Bonert A, Frey C, Schussel K, Muller WE (2003) Mitochondrial dysfunction, apoptotic cell death, and Alzheimer's disease. Biochem Pharmacol 66:1627-1634. doi: 10.1016/S0006-2952(03)00534-3 
Eckert A, Hauptmann S, Scherping I, Meinhardt J, Rhein V, Drose S, Brandt U, Fandrich M, Muller WE, Gotz J (2008) Oligomeric and fibrillar species of beta-amyloid (Abeta42) both impair mitochondrial function in P301L tau transgenic mice. J Mol Med 86:1255-1267. doi:10.1007/s00109-008-0391-6

Fernandez-Vizarra P, Fernandez AP, Castro-Blanco S, Serrano J, Bentura ML, Martinez-Murillo R, Martinez A, Rodrigo J (2004) Intra- and extracellular Abeta and PHF in clinically evaluated cases of Alzheimer's disease. Histol Histopathol 19:823-844

Gibson GE, Huang HM (2002) Oxidative processes in the brain and non-neuronal tissues as biomarkers of Alzheimer's disease. Front Biosci 7:d1007-d1015. doi:10.2741/gibson

Hauptmann S, Scherping I, Drose S, Brandt U, Schulz KL, Jendrach M, Leuner K, Eckert A, Muller WE (2008) Mitochondrial dysfunction: an early event in Alzheimer pathology accumulates with age in AD transgenic mice. Neurobiol Aging. [Epub ahead of print]

Hirai K, Aliev G, Nunomura A, Fujioka H, Russell RL, Atwood CS, Johnson AB, Kress Y, Vinters HV, Tabaton M, Shimohama S, Cash AD, Siedlak SL, Harris PL, Jones PK, Petersen RB, Perry G, Smith MA (2001) Mitochondrial abnormalities in Alzheimer's disease. J Neurosci 21:3017-3023

Jin LW, Hua DH, Shie FS, Maezawa I, Sopher B, Martin GM (2002) Novel tricyclic pyrone compounds prevent intracellular APP C99-induced cell death. J Mol Neurosci 19:57-61. doi: 10.1007/s12031-002-0011-9

Keil U, Bonert A, Marques CA, Scherping I, Weyermann J, Strosznajder JB, Muller-Spahn F, Haass C, Czech C, Pradier L, Muller WE, Eckert A (2004) Amyloid beta-induced changes in nitric oxide production and mitochondrial activity lead to apoptosis. J Biol Chem 279:50310-50320. doi:10.1074/jbc.M 405600200

Krahenbuhl S, Chang M, Brass EP, Hoppel CL (1991) Decreased activities of ubiquinol:ferricytochrome c oxidoreductase (complex III) and ferrocytochrome c:oxygen oxidoreductase (complex IV) in liver mitochondria from rats with hydroxycobalamin[c-lactam]-induced methylmalonic aciduria. J Biol Chem 266:20998-21003

Leuner K, Hauptmann S, Abdel-Kader R, Scherping I, Keil U, Strosznajder JB, Eckert A, Muller WE (2007) Mitochondrial dysfunction: the first domino in brain aging and Alzheimer's disease? Antioxid Redox Signal 9:1659-1675. doi:10.1089/ars. 2007.1763

Lowry OH, Rosebrough NJ, Farr AL, Randall RJ (1951) Protein measurement with the Folin phenol reagent. J Biol Chem 193:265-275

Lustbader JW, Cirilli M, Lin C, Xu HW, Takuma K, Wang N, Caspersen C, Chen X, Pollak S, Chaney M, Trinchese F, Liu S, Gunn-Moore F, Lue LF, Walker DG, Kuppusamy P, Zewier ZL, Arancio O, Stern D, Yan SS, Wu H (2004) ABAD directly links Abeta to mitochondrial toxicity in Alzheimer's disease. Science 304:448-452. doi:10.1126/science.1091230

Mattson MP, Liu D (2002) Energetics and oxidative stress in synaptic plasticity and neurodegenerative disorders. Neuromolecular Med 2:215-231. doi:10.1385/NMM:2:2:215

Parker WD Jr, Parks J, Filley CM, Kleinschmidt-DeMasters BK (1994) Electron transport chain defects in Alzheimer's disease brain. Neurology 44:1090-1096

Rasmussen UF, Rasmussen HN (2000) Human quadriceps muscle mitochondria: a functional characterization. Mol Cell Biochem 208:37-44. doi:10.1023/A:1007046028132

Rhein V, Eckert A (2007) Effects of Alzheimer's amyloid-beta and tau protein on mitochondrial function-role of glucose metabolism and insulin signalling. Arch Physiol Biochem 113:131-141

Scheuermann S, Hambsch B, Hesse L, Stumm J, Schmidt C, Beher D, Bayer TA, Beyreuther K, Multhaup G (2001) Homodimerization of amyloid precursor protein and its implication in the amyloidogenic pathway of Alzheimer's disease. J Biol Chem 276:3392333929. doi:10.1074/jbc.M105410200

Swerdlow RH, Kish SJ (2002) Mitochondria in Alzheimer's disease. Int Rev Neurobiol 53:341-385. doi:10.1016/S0074-7742(02) 53013-0 